\title{
KAJIAN MORFOLOGI DAN LEGAL FORMAL KEDHATON DAN LINGKUNGAN BALUWARTI KRATON SURAKARTA SEBAGAI KAWASAN HERITAGE Studi Kasus : Kota Surakarta
}

\author{
Rahmawati Prasetyan Darini \\ Prodi Perencanaan Wilayah dan Kota Universitas Islam Sultan Agung Semarang \\ Penulis Korespondensi e-mail : rahmawatiprastyandarini@gmail.com
}

\begin{abstract}
In the village of Sala Village Baluwarti. The Palace itself is an area that is composed of several places and spaces that make up the single entity are hierarchical and specific classified into sacred space, sacred and profane axis. The magical 5,000 concept with the existence of "the Center" as the core of the sacredness, dualistis with orintasi utra-South and East-West (Garden in Marlina Avi, 2017).

This research aims to know the heritage city centre the morphology of structurally and functionally can be achieved by identifying the target Division of space or the structure of the existing area in the Centre of the heritage morphological identification and also functionally can be seen based on the function of sacred, sacred and profane space axes as well as formal legal identifkasi. The methods used in this research is qualitative diskriptif method, where the analysis is performed with the menajdikan theory of deductive process as a start to conduct research in field to produce the findings.

structurally the town heritage-culture that exists in Surakarta consists of territory within the fortress, State and negaragung. As for functionally consists of sacred space, sacred and profane space Axes where each function exists which still has same function either at the time of work as well as at present, but there are also some buildings are undergoing a change of function. As well as formal legal status for a Carton of Surakarta is a nation's cultural relics in ataur in article 1 Kepres No. 23 years of 1988 that the formal legal belongs to the Kraton Surakarta.
\end{abstract}

Keyword : Morphology,Legal Formal, Cites of Kingdom

\begin{abstract}
ABSTRAK
Surakarta merupakan kota yang berada di Provinsi Jawa Tengah dimana pada kota tersebut dulunya merupakan salah satu bekas peninggalan Kerajaan islam yang berdiri pada tahun $1745 \mathrm{M}$ dengan kraton yang berada di Desa Sala Kelurahan Baluwarti. Kraton sendiri merupakan suatu kawasan yang terdiri dari beberapa tempat dan ruang yang membentuk satu kesatuan secara hirarkis dan spesifik yang terklasifikasi menjadi ruang sakral, profane dan sumbu sakral. Konsep kosmo-magis dengan keberadaan "pusat" sebagai inti kesakralan, dualistis dengan orintasi utra-selatan dan timur-barat (Garden dalam Marlina Avi, 2017).

Penelitian ini bertujuan untuk mengetahui morfologi pusat kota peninggalan kerajaan secara struktural dan fungsional yang dapat dicapai dengan sasaran melakukan identifikasi pembagian ruang atau struktur wilayah yang ada di pusat kota peninggalan kerajaan dan juga identifikasi morfologi secara fungsional yang dapat dilihat berdasarkan fungsi sakral, sumbu sakral dan ruang profane serta identifkasi legal formal. Metode yang digunakan pada penelitian ini adalah metode diskriptif kualitatif, dimana analisis dilakukan dengan proses deduktif yang menajdikan teori sebagai awal untuk melakukan penelitian dilapangan hingga menghasilkan temuan.

secara struktural Kota peninggalan kerjaan yang ada di Surakarta terdiri dari Wilayah dalam Benteng, Negara dan negaragung. Adapun secara fungsional terdiri dari ruang Sakral, Sumbu sakral dan ruang profane dimana pada masing-masing fungsi ada yang masih memiliki fungsi sama baik pada masa kerjaan maupun saat ini namun ada pula beberapa bangunan yang mengalami perubahan fungsi. Serta untuk status legal formal Karton Surakarta yang merupakan peninggalan budaya bangsa yang di ataur dalam Pasal 1 Kepres No. 23 Tahun 1988 bahwa legal formal adalah milik Kraton Surakarta.
\end{abstract}

Kata Kunci : Morfologi,Legal Formal Kota Kerajaan 
Jurnal Planologi Vol. 15, No. 1, April 2018

Available : http://jurnal.unissula.ac.id/index.php/psa

\section{PENDAHULUAN}

Kota merupakan tempat tinggal beberapa ribu penduduk, adapun perkotaan adalah area terbangun yang dilengkapi dengan struktur dan jalan, sebagai suatu permukiman terpusat pada suatu area dengan kepadatan tertentu(Branch Melville, 1996). Kota juga diartikan sebagai wadah dengan kepadatan penduduk tinggi, yang sebagian besar lahannya merupakan lahan terbangun dengan perekonomian bersifat non-pertanian. Lingkungan perkotaan memiliki formasi atau keadaan suatu kota dapat diselidiki secara struktural, fungsional dan visual atau yang lebih sering dikenal dengan morfologi perkotaan (Zahnd Markus, 1999). Terdapat tiga unsur pembentuk morfologi kota antara lain penggunaan lahan, pola jaringan jalan, dan tipe bangunan, dari ketiga unsur tersebut muncullah istilah Townscape untuk pertama kali.

Indonesia sendiri merupakan salah satu Negara yang terdiri dari beberapa kawasan, dimana pada beberapa waktu lalu nama Indonesia, wilayah yang terbantang dari Sabang sampai Merauke tersebut juga dikenal dengan nama Nusantara. Disebut Nusantara mengingat kawasan di Indonesia terdiri dari bebagai pulau-pulau yang mana beberapa bagian dari pulau-pulau tersebut dulunya merupakan pusat kerajaan-kerajaan besar (Achmad, wintala, 2016).

Salah satu Kota yang merupakan bekas pusat kerjaan yang ada di Indonesia adalah Kota Surakarta. Surakarta merupakan kota yang berada di Provinsi Jawa Tengah dimana pada kota tersebut dulunya merupakan salah satu bekas peninggalan Kerajaan islam yang berdiri pada tahun 1745 M dengan kraton yang berada di Desa Sala Kelurahan Baluwarti. Kraton sendiri merupakan suatu kawasan yang terdiri dari beberapa tempat dan ruang yang membentuk satu kesatuan secara hirarkis dan spesifik yang terklasifikasi menjadi ruang sakral, profane dan sumbu sakral. Konsep kosmo-magis dengan keberadaan "pusat" sebagai inti kesakralan, dualistis dengan orintasi utra-selatan dan timur-barat (Garden dalam Marlina Avi, 2017).

Mengingat kawasan kraton merupakan salah satu kawasan khusus dimana pada kawasan ini merupakan kawasan dengan fungsi cagar budaya tentu akan memiliki ketentuan dan susunan yang berbeda dengan kota pada umumnya. Jika kota pada umumnya secara struktural dapat dibedakan menjadi pusat kota, sub pusat kota dan kawasan pinggiran sebagaimana yang terdapat dalam buku Struktur Kota Yunus, 2012. Kawasan kraton memiliki susunan yang cukup berbeda dimana susunan pada kawasan kraton atau kota kerajaan terdiri dari Kedhaton, Negara dan Negaragung. 
Selain struktur pada kawasan kraton atau kota kerjaan status legal formal yang ada di dalamnya pun juga dirasa perlu dilakukan identifikai atau kajian secara mendalam, karena legal formal ini merupakan salah satu hal penting yang menjadi pertimbangan dalam menentukan kebijakan.

Tujuan dari penelitian ini adalah untuk menemukan morfologi secara struktural dan fungsional kota peninggalan kerajaan Islam di Surakarta dan status legal formal pada lingkungan kedahton dan Kelurahan Baluwarti.

Permasalahan yang akan dibahas dalam penelitian ini antara lain:

1) Bagaimanakah morfologi pusat kota peninggalan kerajaan secara struktural di Surakarta?

2) Bagaimanakah morfologi pusat kota peninggalan kerajaan secara fungsional di Surakarta?

3) Bagaimanakah status legal formal pusat kota peninggalan kerajaan di Surakarta?
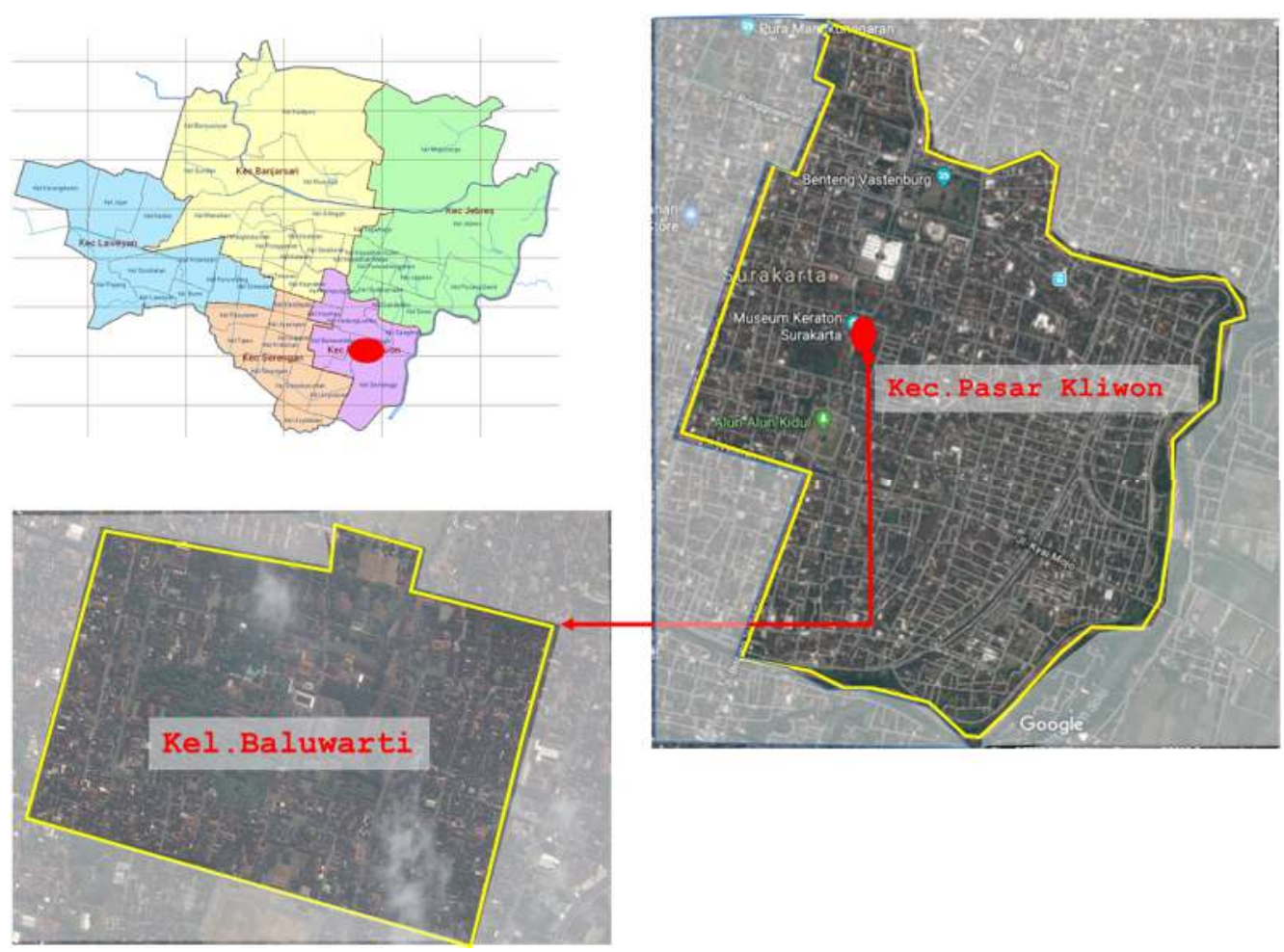

Gambar 1. Peta Orientasi Kota Surakarta Sumber : Identifikasi Lapangan, 2018 


\section{METODOLOGI}

Metode yang digunakan pada penelitian ini adalah metode diskriptif kualitatif rasionalistik, dimana analisis dilakukan dengan proses deduktif yang menjadikan teori sebagai awal untuk melakukan penelitian dilapangan hingga menghasilkan temuan. Sikap rasionalistik digunakan tidak hanya menunjukkan data-data primer dan sekunder, tetapi mendeskripsikan arti dari makna yang berupa gambaran dari sebab akibat di setiap fakta yang terjadi dilapangan sehingga dapat ditarik kesimpulan tautan keterhubungannya. (Rahman, 2017). Aspek rasionalistik akan memberikan gambaran terkait hubungan sebab akibat dan kondisi eksisting yang terjadi di kawasan perencanaan.

\section{Kajian Teori}

Morfologi terbentuk oleh kata morf memiliki makna bentuk dan logos memiliki makna ilmu. Dengan melihat kedua makna kata tersebut maka morfologi kota dapat dimaknai sebagai ilmu yang mengkaji terkait fisik kota terutama dalam aspek bentuk fisik kota. Morfologi menjadi pendekatan mempelajari bentuk logis sebuah kota sebagai produk perubahan sosio-spatial. Tipologi mempunyai hubungan yang kuat terhadap ikmu morfologi, hal ini merujuk bahwa karakteristik sosio-spatial masing-masing lokasi berbeda-beda. Bila morfologi adalah bentuk kota skala besar maka tipologi menjelaskan terkait skala kecil. Beberapa definisi morfologi berbdasarkan pendekatannya adalah :

1. Menurut Kostof bahwa kota adalah tempat kumpulan bangunan dan manusia (cities are place made up of buildings and people) (Weishaguna dan Ernady, 2007)

2. Menurut Sandi Siregar, kota adalah artifak yang dihuni. Kota sebagai lingkungan buatan manusia yang memperlihatkan karya anjiniring besar dan kompleks, terdiri dari kumpulan bangunan (dan elemen-elemen fisik lainnya) serta manusia dengan konfigurasi tertentu membentuk satu kesatuan ruang fisik (physical-spatial entity) (Weishaguna dan Ernady, 2007)

3. Menurut E.N. Bacon bahwa kota adalah artikulasi ruang yang memberikan suatu pengalaman ruang tertentu kepada partisipator. Oleh karena itu, lingkup perhatian perancang kota akan lebih lengkap jika meliputi bangunan, setting dan karakter kota (Weishaguna dan Ernady, 2007)

4. Menurut Ali Madanipour bahwa kota adalah kumpulan berbagai bangunan dan artefak (a collection of buildings and artefact) serta tempat untuk berhubungan sosial (a site for social relationships). Morfologi kota merupakan suatu geometri 
dari proses perubahan keadaan yang bersifat sosio-spatial (the geometry of a sociospatial continuum) (Weishaguna dan Ernady, 2007)

5. Menurut Also Rossi bahwa kota adalah karya kolektif (Weishaguna dan Ernady, 2007).

6. Menurut Paul D. Spereiregen juga menekankan pada pengertian kota sebagai bentukan fisik yang secara keseluruhan saling mengisi satu sama lainnya dan membentuk satu kesatuan penampilan kota (Weishaguna dan Ernady, 2007).

7. Kota menurut Gallion and Eisner(1992) adalah suatu laboratorium tempat pencarian kebebasan dilaksanakan dan percobaan-percobaan diuji mengenai bentukan-bentukan fisik. Bentukan-bentukan fisik kota adalah perwujudan kehidupan manusia ; polanya dijalin dengan pikiran dan tangan yang dibimbing oleh suatu tujuan. Bentukan fisik kota terjalin dalam aturan yang juga mengemukakan lambang-lambang pola-pola ekonomi, sosial, politis dan spiritual serta peradaban masyarakatnya. Kota adalah tempat mengaduk kekuatan-kekuatan budaya dan rancangan kota merupakan ekspresinya (Weishaguna dan Ernady, 2007)

Dari beberapa pengertian di atas dapat ditarik suatu rumusan bahwa morfologi kota adalah sebuah pendekatan dalam memahami kota sebagai suatu kumpulan geometris bangunan dan artefak dengan konfigurasi kesatuan ruang fisik tertentu produk dari perubahan sosio-spatialnya (Weishaguna dan Ernady, 2007)

Teori struktural lebih menekankan kepada mobilitas tempat tinggal dan yang dikaitkan dengan "taste, preference, dan life styles" pada suatu kota (Yunus, 2012). Dari pendekatan tersebut maka Alonso dalam Yunus, 2000 menyebutkan adanya fakta bahwa daerah zona 2 adalah zona transisi yang mengalami deteriosasi lingkungan yang cukup parah yang diakibatkan dari invansid an infiltrasi fungsi-fungsi yang ada di zona 1. Adanya percampuran fungsi menjadikan kawasan atau areal tempat tinggal terganggu, sehingga "taste and preference" penduduk zona 2 memiliki tingkat yang sangat rendah. Hal ini mendorong terjadinya perpindahan penduduk dari zona ini kebagian-bagian luar (Yunus, 2000). 

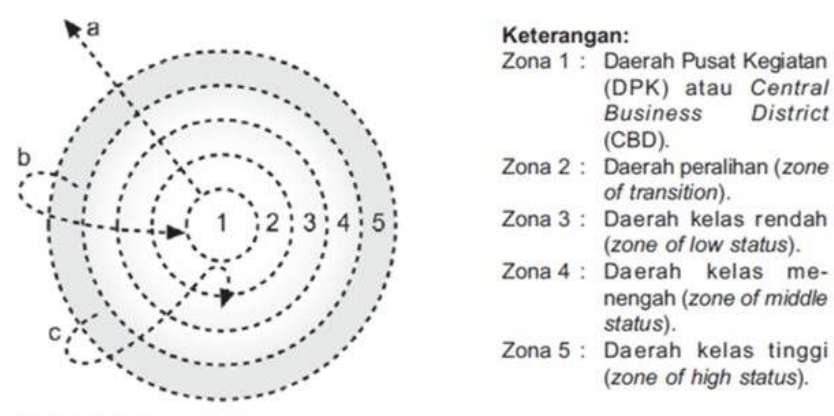

Gambar 2. Model Teori Struktural

Sumber : Hadi Sabari Yunus, 2000

Secara struktural konsep tata ruang jawa pada periode pra kolonial mengacu pada prinsip mirokosmos hirarkis (Sunaryo, 2015). Kedua konsep ini mengacu pada prinsipnya bahwa raja adalah pusat dunia (mikrokosmis hierarkis) dan raja sebagai pengatur keseimbangan alam semesta (mikrokosmos dualistis). Penerapan mikrokosmos hierarkis pada penetapan wilayah-wilayah yang masuk kepada wilayah pusat (Keraton-Negaragung) hingga wilayah terluar (mancanegara). Soemardjan 1962 dalam Sunaryo Gunawan, 2015 menggambarkan bahwa konsep kota dan negara dalam tata ruang Jawa-Mataram berbentuk suatu sistem lingkaran terdalam adalah wilayah paling sakral dari kota/negara, semakin keluar dari lingkaran pusat maka tingkat kesakralan bergerak ke arah profan. Pusat dari sistem lingkaran tersebut adalah sultan yang memerintah dengan kesaktian yang dimilikinya. Adapun Sultan dalam sistem keruangan adalah keraton dengan wilayah yang dikelilingi benteng dalam hal ini yang dimaksud benteng adalah dalam artian luas seperti pagar keliling atau sejenisnya. Sementara itu konsep negara sendiri adalah sebuah wilayah yang ada di luar benteng dengan komponen seperti alun-alun, masjid agung, dan gedung pemerintahan penting. Lingkaran terluar dari konsep tata ruang ini adalah mancanegara, yang merupakan wilayah-wilayah otonom, tetapi tunduk dan mengaku kedaulatan sultan. Pada konteks ini mancanegara pada sistem keruangan kraton berbeda dengan istilah mancangera saat ini yang berarti adalah wilayah diluar administrasi suatu Negara.

Pada umumnya wilayah keraton tidak mengalami perubahan secara fisik kecuali terjadi suksesi, untuk wilayah negaragung dan mancanegara bersifat dinamis tergantung ada besar kekuasan raja pada periode tertentu. Konsep mikrokosmos dualistis cenderung lebih mudah dipahami karena terlihat dalam wujud fisik. Penerapan prinsip mikrokosmosdualistis bertujuan untuk menghadirkan keseimbangan dua elemen yang berlawanan dalam semesta. Santoso (2008) mengangkat kembali kajian Van Ossenbruggen di 1917 tetang konsep mancapat di Pulau jawa sebagai dialog dengan konsep mikrokosmos -dualitsis. 
Konsep mancapat secara filosofis merupakan titik tengah yang berkoordinasi dengan empat penjuru yang mengelilinginya. Pada wujud fisik, persekutuan sebuah desa dengan empat desa lain disekelilingnya adalah wujud konsep mancapat . konsep ini dikaitkan juga dengan perempatan sakral yang dihopetasakan Pegeaud 1962 dalam (Sunaryo, 2015) pada saat merekonstruksi pusat kota Majapahit. Perempatan suci ini merupakan titik temu dari dua sumbu tegak lurus yang menjadi sumbu pencerminan dari elemen-elemen kembar yang mencerminkan keseimbangan dualistis di pusat kota majapahit. Pada kota-kota jawa setelah majapahit, wujud perempatan sakral ini pada umumnya merupakan alun-alun kota yang menjadi titik pertemuan empat jalan utama dari luar kota. Baik (Handinanta, 2010) berpendapat sama bahwa pada kota-kota Jawa pasca Majapahit sumbu-sumbu yang terbentuk di pusat kota ini merupakan penghubung sekaligus pemisah antara ruang sakral (istana,kota, keraton) dan ruang profan (pasar, wilayah luar kota).

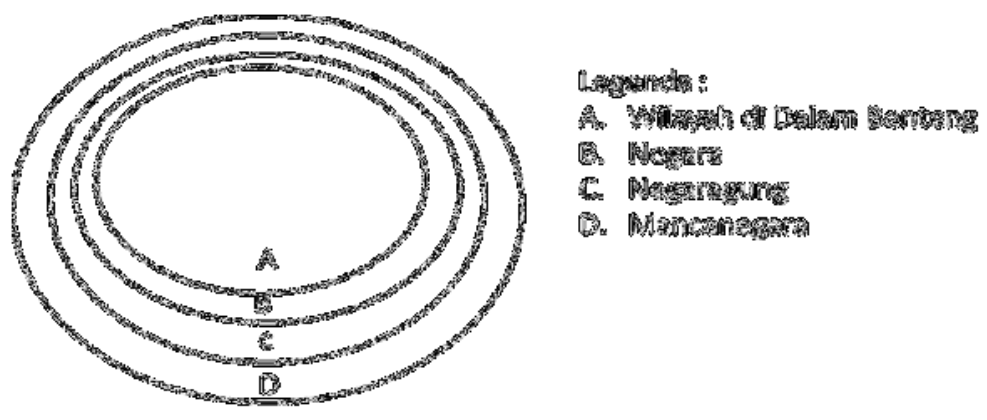

Gambar 3. Elemen Mikrokosmos Hirarkis Kota Tradisional Jawa Sumber : Santoso dalam Sunaryo Gunawan, 2015
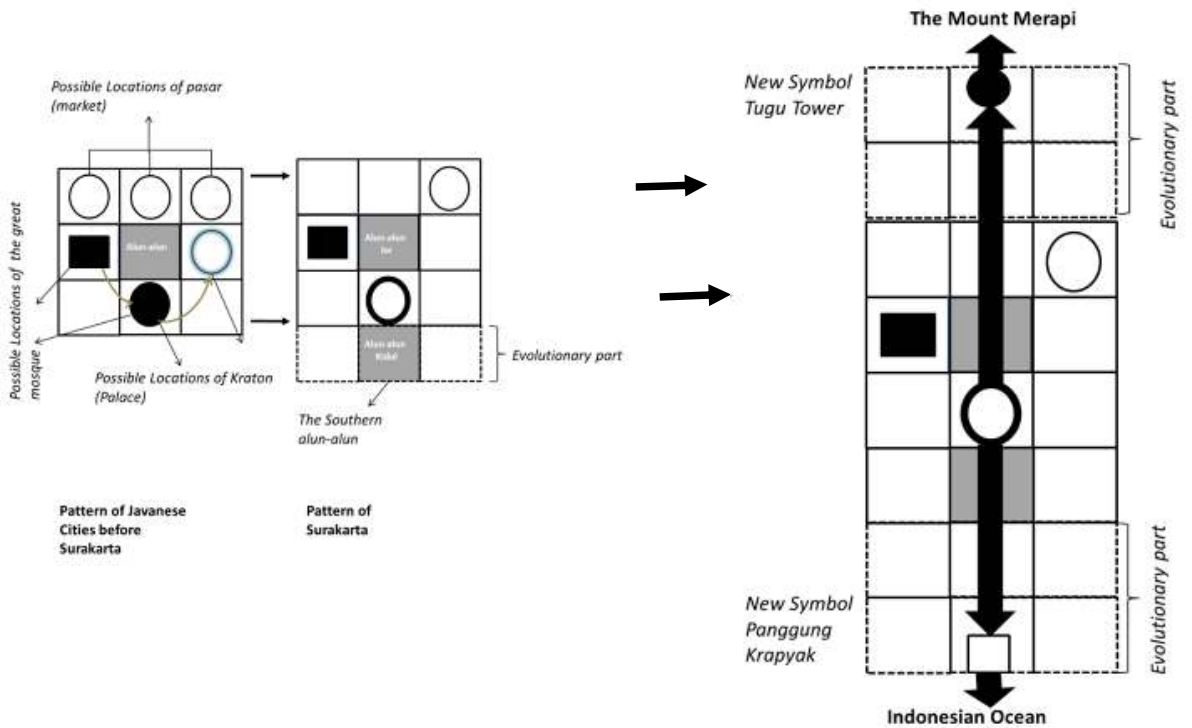

Gambar 4. Evolusi Pola Catur Tunggal Kota Tradisional di Indonesia Sumber : Ikaputra, 1995 


\section{PEMBAHASAN}

\section{Morfologi Struktural Kraton Surakarta Hadiningrat}

Secara struktural morfologi pada pusat kota peninggalan Kerajaan di Surakarta terdiri dari wilayah dalam benteng yang meliputi seluruh wilayah karaton, Negara yang mencakup seluruh wilayah administrasi Kelurahan Baluwarti dan Negarugung yang mencakup bagian wilayah kekuasaan pada masa kerajaan yang meliputi seluruh wilayah administrasi Kota Surakarta dan sebagian kecil wilayah yang ada di luar administrasi Kota Surakarta.

Wilayah dalam benteng merupakan areal dalam benteng Keraton dengan luas kurang lebih 5 Ha dengan komponen adalah bangunan-bangunan utama karaton seperti yang terdapat pada denah berikut :

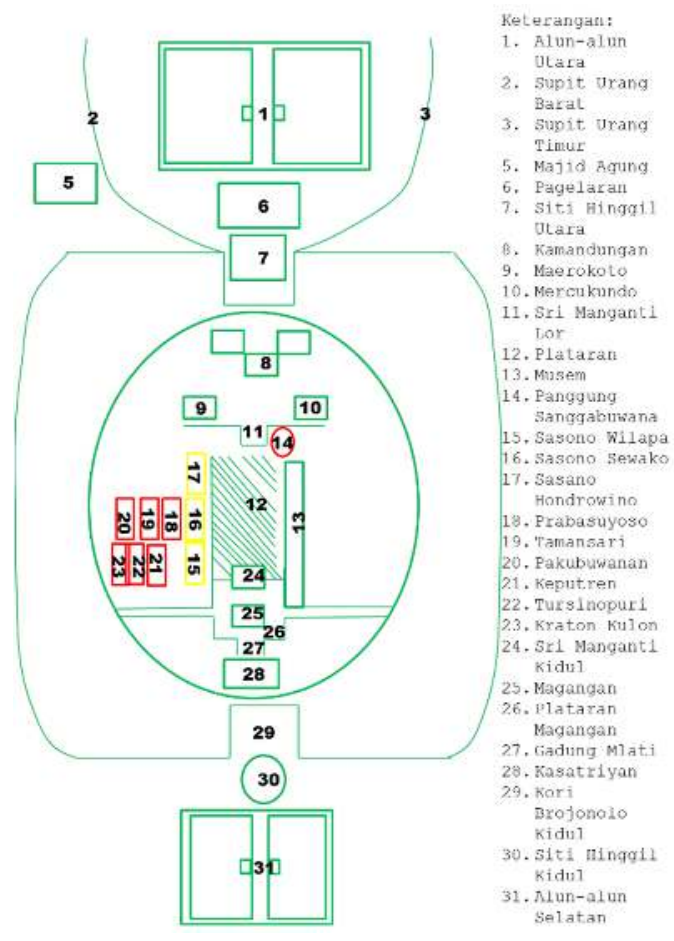

Gambar 5. Susunanan Morfologi Dalam Benteng Sumber : Identifikasi Lapangan, 2018

Wilayah nagari pada keraton Surakarta Hadiningrat meliputi seluruh perkampungan Baluwarti yang merupakan salah satu Kelurahan di Kecamatan Pasar Kliwon 


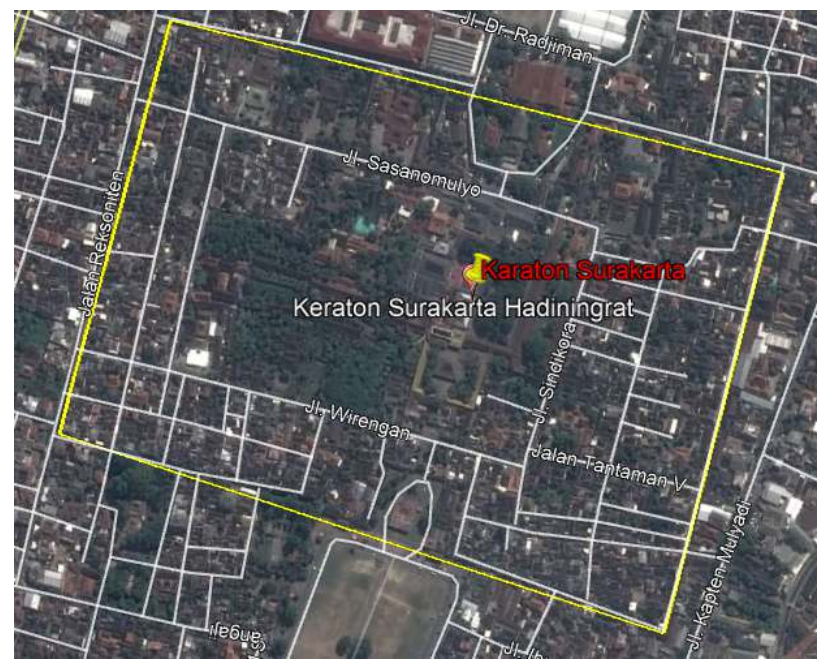

Gambar 6. Wilayah Nagari

Sumber : Googlemap dan Identifikasi Lapangan, 2018

Struktur atau pola jaringan jalan yang terbentuk antara wilayah dalam benteng dengan wilayah Negara adalah pola Savanah atau grid. Pola "Savannah" merupakan pola grid atau sering disebut pola "gridion".

Wilayah negaragung yang ada di Karaton Surakarta mencakup sebagian wilayah administrasi Kota Surakarta dan sebagian wilayah yang berada diluar wilayah administrasi Kota Surakarta.

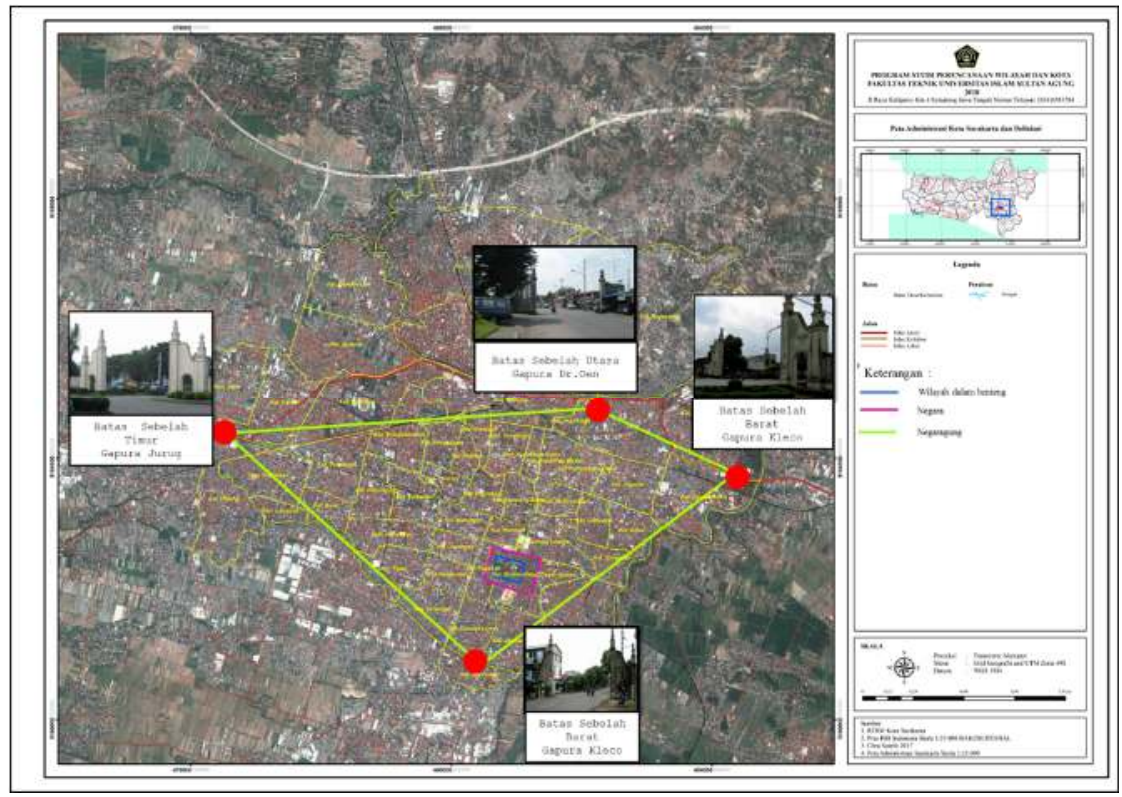

Gambar 7. Wilayah Negaragung Sumber : Identifikasi Lapangan, 2018 


\section{Morfologi Fungsinal Kraton Surakarta Hadiningrat}

Secara fungsional Keraton Surakarta Hadiningrat berdarsarkan parameter dan indikator morfologi kota secaraa fungsional terdiri dari ruang privat, sumbu sakral dan ruang profan. Ruang privat yang ada di Karaton Surakarta meliputi probosuyoso, Keputren, pakubuwanan, tursinopuri dan kraton kulon. Namun demikian pada ruang privat ini terdapat ruang yang memiliki makna sakral atau dianggap sakral. Terdiri dari Pakubuwanan dan proboyekso.

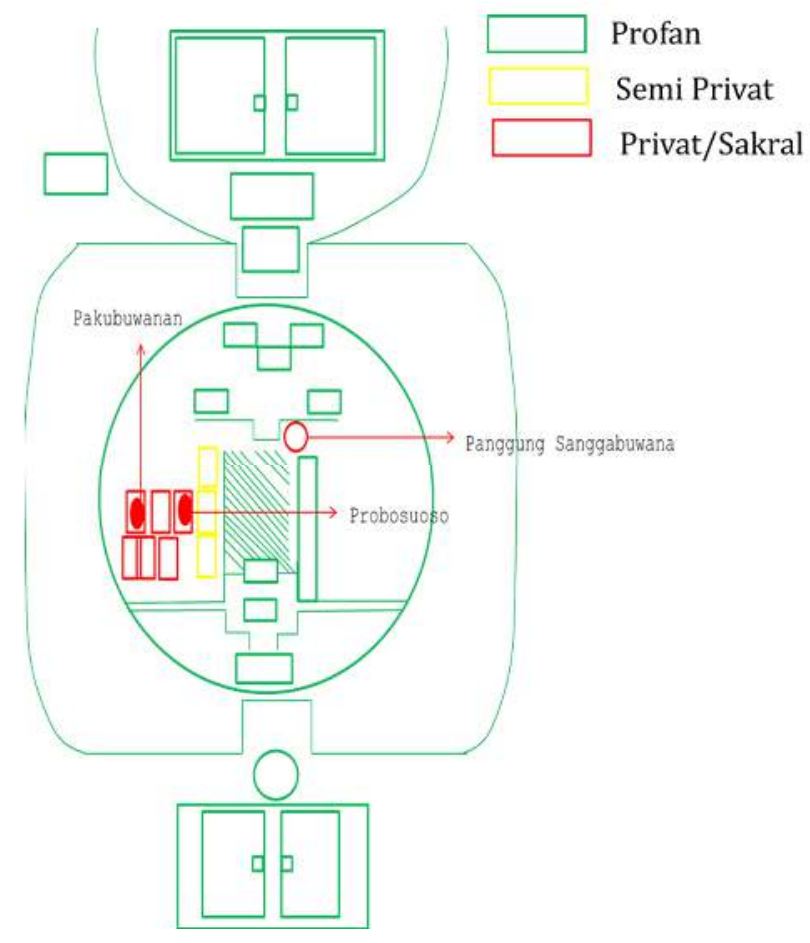

Gambar 8. Klasifikasi Fungsi Pada Susunan Kraton Surakarta Sumber : Identifikasi Lapangan, 2018

Pada Keraton Surakarta Hadiningrat sumbu sakral ini berupa bangunan tinggi yang bernama Panggung Sanggabuwana. Panggung Sanggabuwanamerupakan tempat mediasi raja, untuk berdoa dan bertemu dengan Tuhan. Panggung Sanggabuwanaterdiri dari 5 lantai, yang mana 5 lantai tersebut melambangkan 5 dasar kehidupan yaitu rukun islam, kalimosodo dan 5 pancasila dasar. Lokasi Panggung Sanggabuwanatersebut merupakan pertemuan 4 unsur alam yaitu antara Gunung Lawu, Gunung Merapi, Alas Krondowahono dan Laut Selatan. 


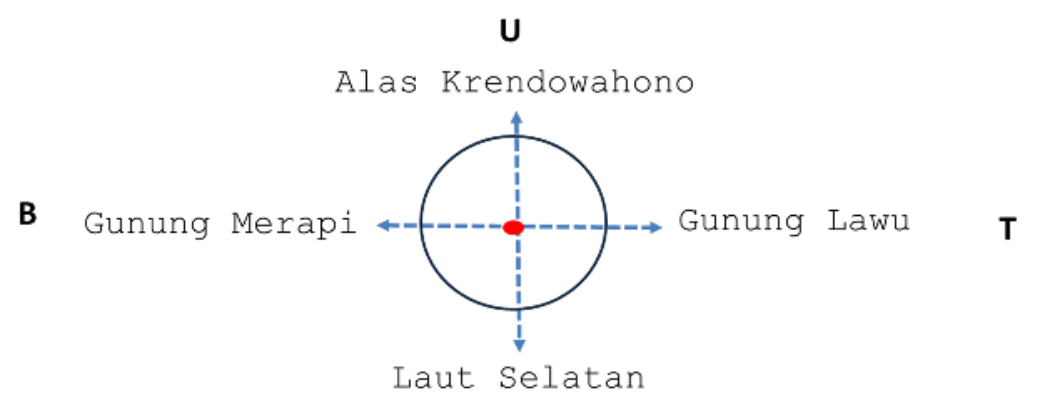

$S$

Gambar 9. Skema Hubungan Panggung Sanggabuwana dengan Alam Sumber : Dokumentasi, 2018

Ruang profan merupakan ruang yang dapat diakses oleh umum. Pada konteks ini ruang yang bersifat profan di Keraton Ksunana Surakarta terdiri dari Alun-alun utara dan selatan, siti hinggil utara dan selatan, masjid agung, pagelaran, kori kamandungan, mercu kundo, smarakata, sasana handrawina, sasano wilapao, sasano sewaka, gadung melati, kemagangan, dan kasatriyan. Beberapa ruang profane yang ada di Kraton Surakarta Hadiningrat ada yang masih memiliki fungsi yang sama dan adapula beberapa yang sudah mengalami perubahan fungsi diantaranya adalah Siti Hinggil Utara dan Selatan serta Kori Kamandhungan. Berikut adalah beberapa kondisi ruang profane yang ada di Kraton Surakarta :

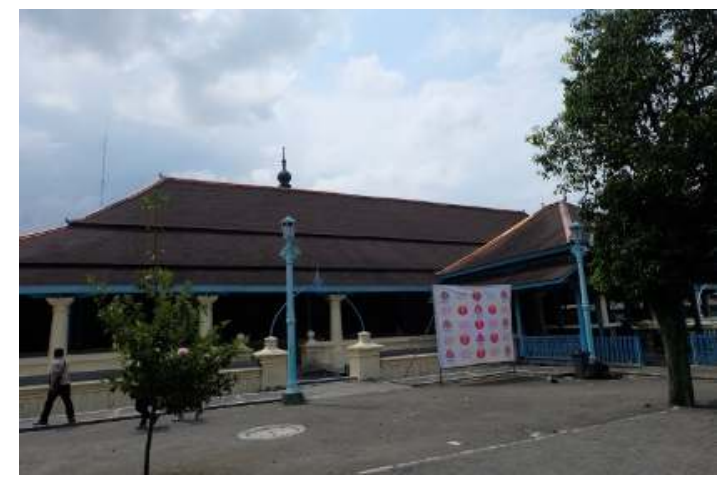

Gambar 10. Masjid Agung Keraton Surakarta Hadiningrat Sumber : Dokumentasi, 2018 


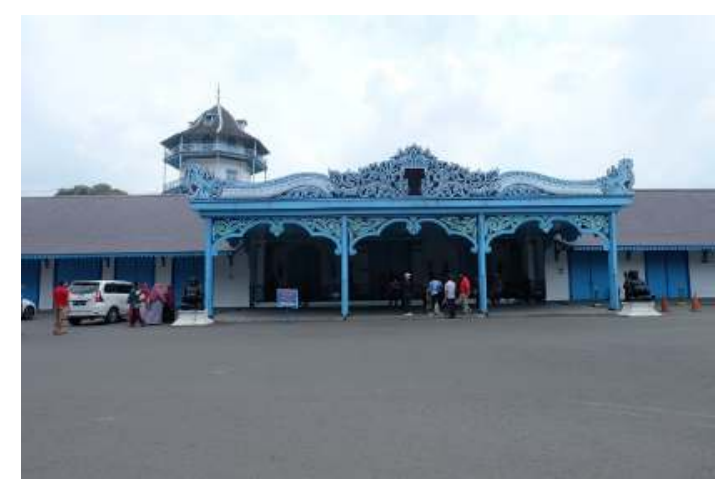

Gambar 11. Kori Kamandhungan Sumber : Dokumentasi, 2018

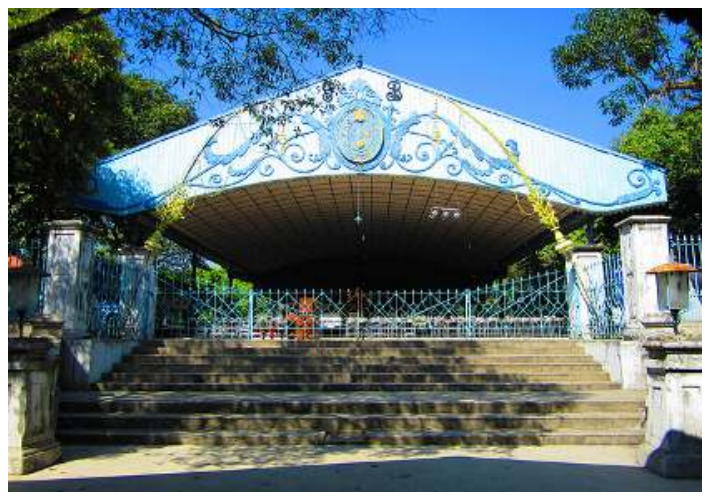

Gambar 12. Siti Hinggil Utara

Sumber : Dokumentasi, 2018

\section{Status Legal Formal}

Hak atas tanah kraton Surakarta di ataur dalam Pasal 1 Kepres No. 23 Tahun 1988 yang menyatakan bahwa tanah dan bangunan keraton kasunanan Surakarta berikut segala kelengkapannya yang terdapat didalamnya (termasuk masjid Agung dan alun-alun keraton) adalah milik kasunanan Surakarta yang perlu dilestarikan sebagai peninggalan budaya bangsa. Ada tiga hal yang tidak dijelaskan dalam Keppres ini yaitu luas, letak dan batas tanah; pengertian milik; dan pengertian kasunanan Surakarta. Ketentuan ini konsisten dengan Pasal 6 UU No. 5 tahun 1992 yang menentukan bangunan keraton Surakarta sebagai benda cagar budaya adalah milik Sinuhun.

Ada tiga hal yang tidak dijelaskan dalam Kepres ini yaitu luas, letak dan batas tanah; pengertian milik; dan pengertian kasunanan Surakarta. Menurut Darsiti Soeratman, walaupun pada masa yang panjang itu bangunan keraton mengalami perkembangan secara terus menerus, namun pembagian pelataran atau halaman tidak mengalami perubahan. Dalam hal ini konsep empat lingkaran kerajaan Jawa dipakai untuk pembagian keraton. Pertama, kedhaton dan sekitarnya yang dilingkungi oleh beteng bata pertama. Kedua, 
wilayah di antara dua beteng yang disebut Baluwarti; ketiga, halaman di luar Kori Brajanala, yaitu paseban, dan keempat, alun-alun.

Status tanah yang ada di Lingkungan Baluwarti dan kawasan kedhaton juga sesuai dengan data status tanah yang ada di pemetaan Badan Pertanahan Nasional. Dimana pada kawasan Baluwarti status tanah tergambar sebagai tanah dengan Hak Guna Bangunan, artinya masyarakat secara umum tidak diperkenankan memiliki status tanah yang ada di dalam lingkungan Kraton.

Kondisi eksisting saat ini tanah pada lingkaran kedua atau Baluwarti saat ini tidak hanya ditempati oleh abdidalem melainkan juga beberapa ada masyarakat biasa yang menempatinya dengan status kepemilakan tanah adalah Hak Guna Bangunan.

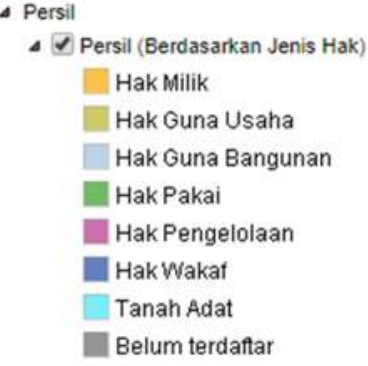

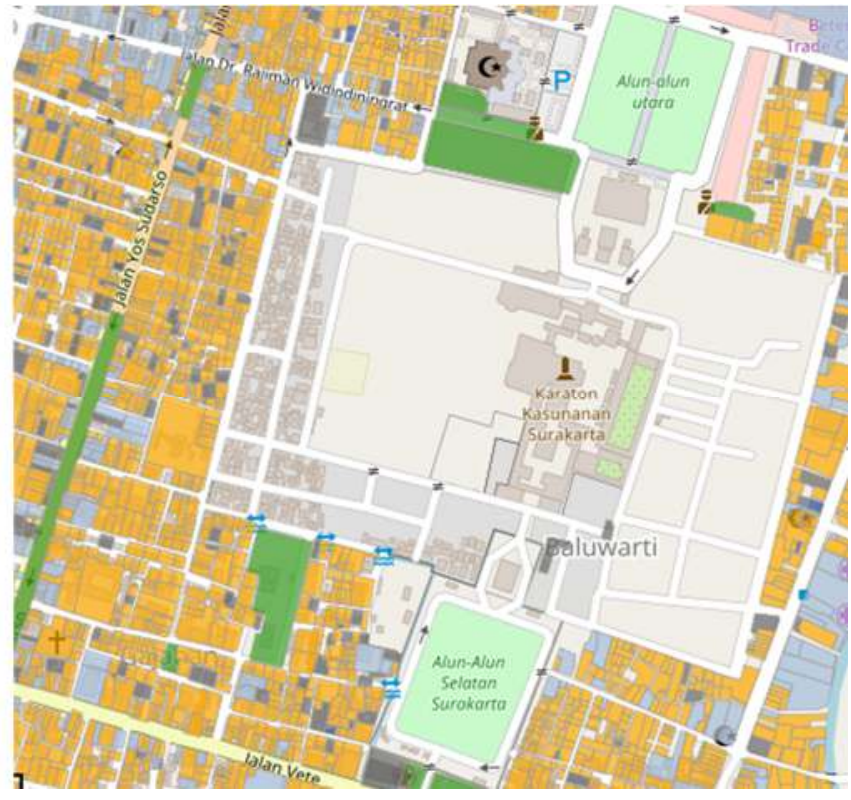

Gambar 13. Status Tanah Kraton Surakarta Sumber : Peta.bpn.go.id,2018

\section{KESIMPULAN DAN SARAN}

\section{Kesimpulan}

Kesimpulan dari penelitian ini diketahui bahwa secara struktural Kota peninggalan kerjaan yang ada di Surakarta terdiri dari Wilayah dalam Benteng, Negara dan negaragung. Adapun secara fungsional terdiri dari ruang Sakral, Sumbu sakral dan ruang profane dimana pada masing-masing fungsi ada yang masih memiliki fungsi sama baik pada masa kerjaan maupun saat ini namun ada pula beberapa bangunan yang mengalami perubahan fungsi. Serta untuk status legal formal Karton Surakarta yang merupakan peninggalan 
budaya bangsa yang di ataur dalam Pasal 1 Kepres No. 23 Tahun 1988 bahwa legal formal adalah milik Kraton Surakarta.

\section{Saran}

Saran untuk semua pihak terutama yang berkecimpung dalam bidang Heritage adalah sebagai berikut :

1. Wawasan akan sejarah pembangunan atau pembentukan tanah jawa yang sudah banyak terliput dalam buku "Babad Jawa" sebisa mungkin terus disosialisasikan mengingat sejarah merupakan bagian yang tidak boleh terlupakan terutama dalam pembangunan wilayah dan kota;

2. Diharapkan kepada pihak-pihak yang memangku kepentingan dalam pembangunan wilayah dan kota tetap memperhatikan sejarah atau historis kota tersebut, sehingga kota akan tetep tumbuh menjadi kota yang berkarakter.

3. Penelitian yang akan datang direkomendasikan memabahas lebih detail dan mengaitkan dengan kerajaan-kerajaan yang ada di Indonesia untuk merunut atau merekonstruksi sketssa dan hubungan sejarah masing-masing kerajaan yang ada di Indonesia.

4. Penelitian lebih mendalam untuk kedua Pusat Kota peninggalan Kerajaan dapat diteliti terkait faktor yang mempengaruhi perkembangan morfologi kedua pusat kota peninggalan kerajaan tersebut.

5. Simbol-simbol maupun ornament sejarah yang ada di kota-kota kerajaan supaya tetap dipertahankan sebagai identitas masa kajayaan kerajaan masa lampau

6. Akademisi supaya lebih banyak melakukan penelitian yang berkaitan dengan sejarah sebagai wujud pelestarian budaya baik dikatikan dengan pembangunan wilayah dan kota atau disiplin ilmu yang lain.

\section{TINJAUAN PUSTAKA}

Branch, Melville. (1996). Perencanaan Kota Komprehensif Pengantar dan Penjelasan Gadjah Mada University Press, Yogyakarta

Budihardjo, E. (1984). Meunuju Arsitektur Indonesia. Bandung : Bandung Alumni.

Carmonara, M, Heath, T., oc, T \& Tiesdell, S. (2003). Public Places Urban Spaces, Teh

Dimensions Of Urban Design Architectural Press. Architectural Press. 
Fadila, A. (2006). Morofologi Kota Sigli. Thesis di Universitas Gadjah Mada.

Handinanta, Y. I. (2010). Tipomorofologi Kota Banjarmasin. Skripsi di Universitas Gajah Joko P, S. (2006). Metode Penelitian (Dalam Teori dan Praktek). Jakarta: PT Rineka Cipta. Marlina, Avi. (2017). Ruang Hunian Keraton Jawa. Desertasi di Universitas Diponegoro Moleong, J. L. (1988). Metodologi Penelitian Kualitatif. Bandung: Remaja Rosdakarya. Parlindungan, J. (2003). Konsep dan Komponen Morfologi. Buku Ajar Universitas Brawijaya

Smailes, R. J. (1995). I. In the Institute of British Geographer Transaction and Paper.

Rahman, B. (2017). Correlation of Cultural Activity of River Bank to Tidal River Transportation Function. dalam International Conference on Coastal and Delta Areas (Vol. 3, hal. 617-624). Semarang

Sri Wintala Achmad. (2016). Sejarah Kerajaan-Kerajaan Besar di Nusantara. Yogyakarta: Araska.

Sunaryo, R. G. (2015). Morfologi Ruang Pusat Kota Jawa Periode Kolonial. Desertasi di Universitas Gajah Mada.

Tallo, A, J. Pratiwi, Yulia \& Astutik, Indri. (2014). Identifikasi Pola Morofologi Kota (Studi Kasus :Sebagian Kecamatan Klojen Kota Malang). Jurnal Perencanaan Wilayah Dan Kota, Vol 25, Nomor 3, hal 213-227.

Trancik, R. (1943). Finding lost space; Theories of urban design. New Jersey, USA : John Wiley \& Sons, Inc,.

Weishaguna dan Ernady, S. (2007). Morofologi Sebagai Pendekatan Memahami Kota. Jurnal Perencanaan Wilayah Dan Kota Unisba, Vol 7, Nomor 2, hal 55-67.

Yunus, S. H. (2012). Struktur Tata Ruang Kota. Yogyakarta: Pusaka Pelajar.

Zahnd, M. (1999). Perencanaan Kota Terpadu. Yogyakarta: Kanisius.

Zahnd, M. (2008). Model Baru Perancangan Kota yang Kontekstual. Yogyakarta: Kanisius. 